\title{
Explaining farmers' reluctance to adopt recommendations for sustainable ecosystem management
}

\author{
Bezaiet Dessalegn ${ }^{1 *}$ (D, Ludmilla Kiktenko², Balzhan Zhumagazina ${ }^{2}$, Saltanat Zhakenova ${ }^{2}$ and Vinay Nangia $^{3}$
}

\begin{abstract}
Introduction: The lower Syr Darya River Basin is an integral part of the Aral Sea Basin that is shared by four riparian countries. In Kazakhstan, the water is mainly used for agricultural purposes. However, the poor quality and insufficient quantity of water and the overall degradation of natural resources due to unsustainable management practices threaten the profitability of the sector. The situation is even worse for downstream users. Three alternative scenarios for sustainable water and land management were developed using the RIOS and SWAT models as decision support tools. The scenario that offered the highest water and land productivity was presented to farmers to assess their willingness to forgo their current practices and adopt proposed management practices.

We introduce willingness to forego (WTF) - a qualitative approach and a variant of the concept of opportunity costs to look beyond hypothetical markets to trading current benefits for future returns. We also tap into literature on agricultural risk management to provide additional insight into farmers' rationale behind their choices.

Result: Generally, despite their stated preference to conserve ecosystem services, farmers' actions were found to be inconsistent with the proposed sustainable management. WTF analysis revealed that farmers' desire to maximize current benefits and more importantly to minimize future risks override all sustainability considerations. Their WTF current benefits mainly depended on their location along the canal and hence their access to water and land, overall cost of production, market conditions that informed their crop choices, and the cost of adopting recommended packages. While the results remain specific to this case, they are consistent with the literature that links farmers' behaviors to ecological performances.

Conclusions: The study highlights the limitations of decision support tools and other valuation approaches including willingness to pay (WTP) and willingness to accept (payment) (WTA), to capture the delicate trade-offs that need to be considered to ensure household food and income security and encourage adoption of sustainable ecosystem management practices. Adequate information on potential effects of proposed conservation measures on yield, markets and hence farm profits, and availability of other alternatives are critical in shaping farmers' decisions.
\end{abstract}

Keywords: Ecosystem services, Sustainable management, Valuation, Willingness to forego, Risk and uncertainty

\section{Introduction}

Ecosystem services provide direct and indirect benefits to humanity including provisioning services such as fresh water and fuel, regulating services, such as climate and flood regulation, cultural services such as recreational, and esthetic services, and supporting services which cross-cut across the other services, including soil formation and

\footnotetext{
* Correspondence: B.Dessalegn@cgiar.org

'International Center for Agricultural Research in the Dry Areas (ICARDA), P.O.

Box 950764, Amman, Jordan

Full list of author information is available at the end of the article
}

nutrient cycling (MEA 2005). There is a large body of literature that corroborates the ever-growing demand for natural resources and the ensuing ecosystem services. The importance of valuation of ecosystem services is also increasing with growing interest and need to generate supporting evidence for decision makers.

Valuation of ecosystem services is indeed very complex as it goes beyond the environmental and biophysical to include the social, economic, and cultural dimensions that inform society's decision to manage and use ecosystems (Felipe-Lucia et al. 2014). While there is no consensus on 
valuation approaches, the body of literature on the topic offers several approaches that can be used to assess the values ascribed to them (De Groot et al. 2002; Chee 2004; Hein et al. 2006; Liu et al. 2010; Bateman et al. 2011; TEEB 2012; Bagstad et al. 2013). Contingent valuation $(\mathrm{CV})$ is one such analytic approach used to establish stakeholders' stated preferences based on their demand for specific ecosystem service within a hypothetical market (Ciriacy-Wantrup 1947; Garrod and Willis 1999; Shapansky et al. 2002; Cowling et al. 2008; Reed 2008; Luyet et al. 2012; Asamoah and Wiafe 2016).

Under the CV approach, it is assumed that actors can effectively express their willingness to pay (WTP) to continue using ecosystem services or their willingness to accept (payment) (WTA) monetary compensation for forgone services (Hanneman 1991; Diamond 1996; Dasgupta et al. 2000; Farber et al. 2002; Horowitz et al. 2002; Chee 2004). In line with neoclassical economic assumptions, these approaches are primarily based on the notion that users of ecosystem services are rational actors who are fully aware of their value and are hence capable of ranking and choosing from among a list of alternative management scenarios. While conventional economic theory informs us that under most circumstances, the two measures should yield equal estimates or have trivial differences, in reality, the WTA/WTP ratio is higher (Randall 1987; Willing 1976). Among the various explanations offered by literature on environmental economics are biases associated with the individual's budget constraints or motive for profit; substitutability between goods or availability of close substitutes, distribution of income, and the extent of the difference between public and ordinary private goods (Drupp et al. 2017, Baumgartner 2012, Barbier et al. 2016, Horowitz and McConnell 2002, Mansfield 1999, Bateman et al. 1997, Kahneman et al. 1990, Knetsch and Sinden 1984; Knetsch 1990). The debate, however, largely focuses on finding economic explanations for the disparity and the validity of the measures.

While CV for measuring non-market values is widely used to elicit stakeholders' valuation of ecosystem services, it lacks rigor to elicit the reasons behind stated preferences and hence opportunities for policy makers to influence the decision. The authors considered this quite important because society's preferences and valuation of ecosystem services could shift over time depending on changes in economic, environmental, cultural, and institutional norms. Understanding the issues that underpin society's preferences will open up prospects to explore plausible trade-offs to ensure sustainable livelihoods, and avoid major shocks, while pursuing optimal use of ecosystem services.

In this paper, we examine the actual trade-offs associated with NRM decisions by exploring what farmers are willing to forego (WTF) in real terms, and why? As such, the article is intended to compliment WTA and WTA approaches by providing insight into the logic behind farmers' decisions to adopt improved NRM technologies. We applied the concept of agricultural risk management and its underlying assumption that farmers are rational actors that aim to maximize benefit and minimize risks to link farmers' behavior to ecological performance, and sought qualitative explanations for their preferences and associated valuation of ecosystems. We hypothesized that farmers' choices and management decisions are intricately related to real and/or perceived risks and that ecosystem services such as water and land are critical and major limiting factors in agricultural production and hence important components in farmers' risk management strategies and decisions to adopt or not adopt recommended sustainable management practices.

WTF is conceptualized as a variation of opportunity cost which shifts the focus from hypothetical markets in which an assessment is made on how much (in monetary terms) stakeholders are willing to pay/accept to trading ecosystem benefits, i.e., benefits humans derive from ecosystem services by using some built-in capital to realize it (Daily 1997; Fisher et al. 2011). For example, wells provide access to clean drinking water, which represents the benefit from groundwater. WTF thus mainly focuses on the trade-offs between current and future benefits and costs concomitant with the choice for action or inaction within the framework of risk management. The concept of agricultural risk management and its underlying assumption that farmers are rational actors that aim to maximize benefit and minimize risks are central to the WTF approach.

WTF, therefore, minimizes the bias and complexities related with assigning hypothetical monetary values to ecosystem services-be it in terms of anticipation of potential income through WTA or potential monetary cost in the case of WTP which are highly subjective to income disparities within a community (Drupp et al. 2017; Nunes and van den Bergh 2001). It also averts the pitfall of limiting individual choices to their financial capability or need and focuses on practical and plausible trade-offs. When presented together, the results from the quantitative WTP and WTA analyses, and the qualitative WTF analysis will provide more complete insights into farmers' stated preferences, their understanding of the trade-offs among alternative choices, and their willingness to take on associated risks.

The organization of the article is as follows. The next sub-section provides a description of the study area, followed by description of the data used and methods for data collection and analysis. Findings of the study are then presented followed by conclusions that include strategic recommendations for different stakeholders. 


\section{Description of the study area}

The study was undertaken in South Kazakhstan, which is one of the most populated regions of the Republic of Kazakhstan where about 19\% of the total population reside. Agriculture is the main source of income in the area. Income generated from the sector is, however, very low due to insufficient access to good quality and quantity of water, poor infrastructure, inadequate access to improved technologies, and credit services, as well as degradation of natural resources (ICARDA and CAREC 2015; Kiktenko et al. 2015). The lower Syr Darya Riven Basin covers about 128,000 ha and is located in the Turkistan region. Data used in this study was collected from three main villages namely, Bugun, Stary Ikan, and Karachik located at the beginning, middle, and tail end of the Turkistan canal respectively covering a total area of about 36,000 ha (Fig. 1). Stratified sampling was used to select the three villages using location on the canal (upper, middle, or lower tail) as criteria for stratification.

The main market for the region is located at about $9 \mathrm{~km}$ from Karchick, $22 \mathrm{~km}$ from Stary Ikan, and about $30 \mathrm{~km}$ from Bugun. While agriculture in the basin can be generally categorized as a mixed crop-livestock production system, the contribution of livestock to family income varies among the three villages with Bugun and Karachik villages ranking as the highest and the lowest respectively. Water is the scarcest resource in the basin followed by agricultural land which is diminishing due to degradation, expansion of settlements, and fragmentation resulting from population growth. Land holdings also vary across the villages with average land size being the highest in Bugun, followed by Karchik and Stay Ikan.

Rural communities in the study area heavily depend for their livelihoods on the production of cotton, alfalfa, maize, and fruits; fishing; tourism; and raising livestock.
However, unsustainable management of natural resources is resulting in extensive degradation that is negatively affecting crop and water productivity for downstream water users. Among the main challenges are high concentration of pesticides, sediments and sewage carried in the river water from upstream areas, and reduced water availability due to extensive use of inefficient irrigation systems by upstream users (ICARDA and CAREC 2015).

\section{Data}

The study is based on qualitative data collected through desk review, focus group discussions (FGDs), and key informant interviews (KII) held with individuals purposely selected for their knowledge and expertise. As demonstrated in Singh et al. (2011), it is essential to carefully identify selected members of local communities who have historic and in-depth knowledge about farming practices. The FGDs were held with randomly selected farmers from the villages in each stratum, to ensure access to spatial and context-specific information on valuation and use of ecosystem services in the basin. Hence, the study accounted for variations in benefits and risks across the landscape to ensure a robust valuation exercise. Separate FGDs were held with male and female members of the community to capture the views of all members of the community. A total of 12 FGDs were held involving 106 individuals from the three villages (Table 1).

The questions used for the KII and FGD were built on literature on agricultural risk management and previous research on valuation of ESS in the basin which used Soil and Water Assessment Tool (SWAT) and Resource Investment Optimization System (RIOS) models as decision support tools (ICARDA and CAREC 2015). Semi-structured questions were used to solicit relevant

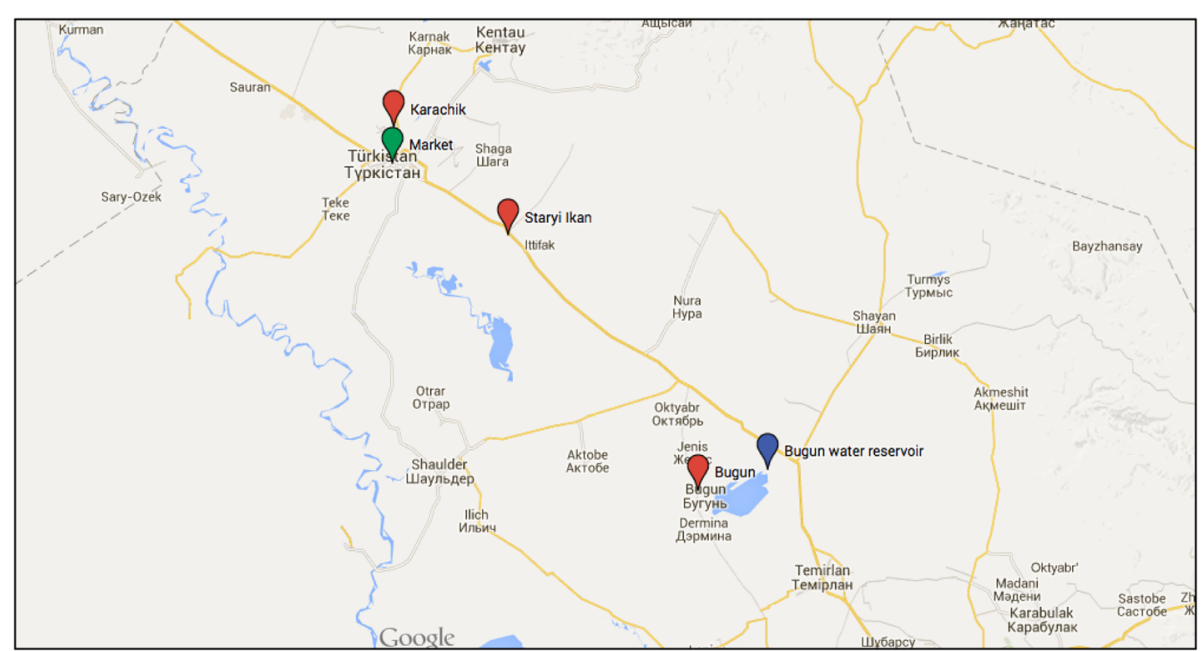

Fig. 1 Lower Syr Darya Basin, Turkestan Region, South Kazakhstan 
Table 1 Focus group formations by village

\begin{tabular}{|c|c|c|c|c|c|c|}
\hline \multirow[b]{2}{*}{ Village name } & \multicolumn{2}{|l|}{ Women } & \multicolumn{2}{|l|}{ Men } & \multicolumn{2}{|l|}{ Total } \\
\hline & Number of FGDs & Number of participants & Number of FGDs & Number of participants & FGDs & Number of participants \\
\hline Bugun & 2 & 21 & 2 & 11 & 4 & 32 \\
\hline Steri Ikan & 2 & 21 & 2 & 17 & 4 & 38 \\
\hline Karachik & 2 & 17 & 2 & 19 & 4 & 36 \\
\hline Total & 6 & 59 & 6 & 47 & 12 & 106 \\
\hline
\end{tabular}

information. The questions were first cleared by the Regional Environmental Center for Central Asia (CAREC) for cultural sensitivity and context applicability and approved by key authorities before being applied. A snow ball method was also used to probe into and get a clearer understanding of the community's stance. Key aspects of the FGDs revolved around questions intended to assess and validate the main challenges to agricultural production in the area focusing mainly on the effects of water scarcity and quality on agricultural activities, and efficiency of traditional irrigation systems. Data on these were collected through individual votes and were analyzed using Likert scale. Other questions sought to explore farmers' crop and irrigation choices by comparing their current practices with proposed alternatives and their WTF existing cropping and irrigation methods in lieu of the

Table 2 Key aspects of the FGDs commonly discussed in every village

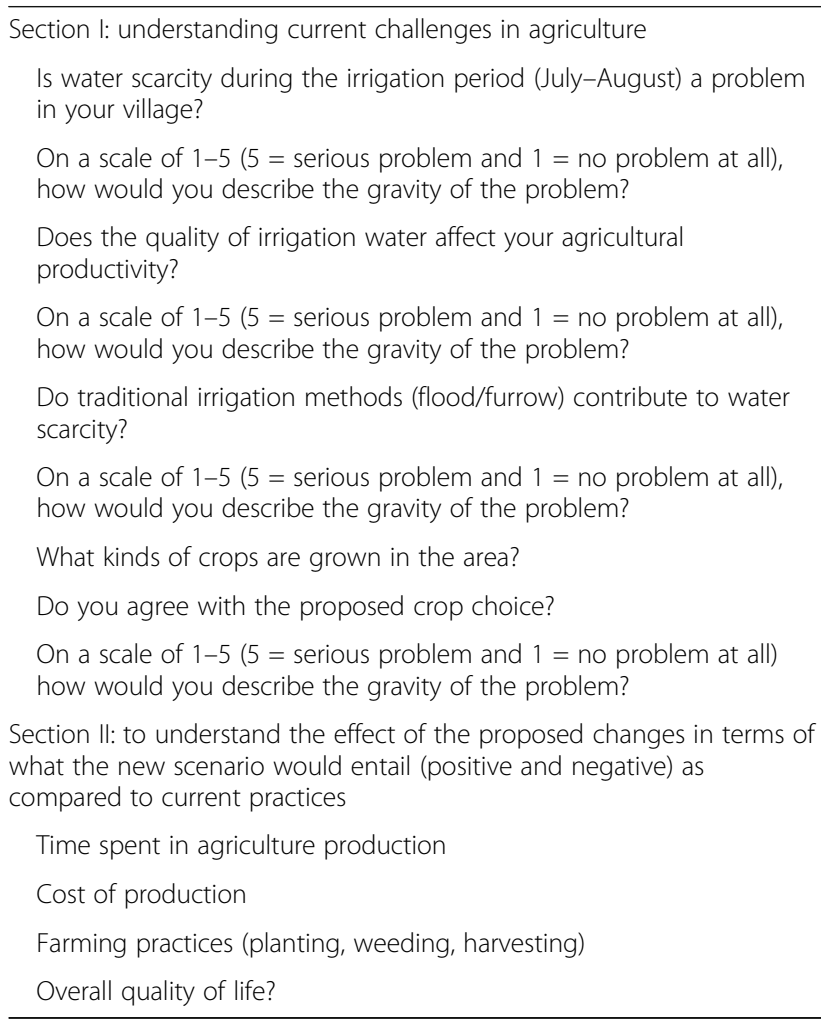

proposed conservation packages (Table 2). The answers were classified summarized and tabulated. These were then thematically analyzed. The themes were deductively generated from the data and literature review and were used to identify similarities and differences among the three villages (Braun and Clarke 2006).

\section{Ethical considerations}

Ethical protocols were considered throughout the data collection process. The interviewees were voluntary. All the individual answers were recorded as confidential information and were analyzed anonymously, to be strictly used for the purpose of the study. This was clearly explained to participants at the beginning of each FGDs and key informant interviews (KII). The research team was given verbal consent to these conditions from all participating individuals. No specific permissions were required from local authorities though they were informed of the study's objectives and plans to collect qualitative information, as well as copies of all proposed questions.

\section{Methods}

The study builds on research conducted on valuation of ecosystem services in the area which used SWAT and RIOS models to assess existing agricultural water management practices and simulate alternative scenarios for ecosystem valuation and water conservation in the three villages. The models used biophysical and economic data on agricultural technologies for commonly grown winter wheat, cotton, and rice. These included water consumption and discharge for the whole Aral-Syr Darya watershed along with the irrigated areas of South Kazakhstan and Kyzyl-Orda provinces, inflow from tributaries and outflow from the Chardara reservoir, and production costs and revenues per hectare for the different crops. The study provided three scenarios for water conservation. The SWAT model identified appropriate crop types and alternative technologies of irrigation, while the RIOS model established key investment options to reduce nitrogen and phosphorus losses and to increase the base flow (Nangia et al. 2015). The models identified three alternative scenarios that could potentially enhance 
water productivity in the basin through introduction of better fertilizer and irrigation water management and substitution of existing crops with more water efficient crops (Table 3).

The cost of adopting the recommended cropping and irrigation packages was estimated at about US $\$ 100$ million. Under the assumption that the financial resource could be made available, the scenarios proposed that farmers in the basin should grow some combination of cotton, alfalfa, and orchards which are traditionally grown in the area but using different irrigation methods depending on the location of the village along the canal and the crop to be planted. Model results showed that the greatest water saving will be achieved under Scenario B which could result in the conservation of up to 229 million cubic meters (MCM) of water in the basin, as compared to scenarios $\mathrm{A}$ and $\mathrm{C}$ which could result in water savings of about 200 and $180 \mathrm{MCM}$, respectively.

More specifically, the decision tools preferentially allocated drip-irrigated orchards and cotton to Bugun village, sprinkler-irrigated alfalfa to Karachick village, drip-irrigated cotton, and sprinkler-irrigated alfalfa for Steri Ikan village (ICARDA and CAREC 2015). It is, however, important to note here that the proposed scenarios are based on strong assumptions including farmers' willingness to (i) adjust their crop choices, (ii) adopt new irrigation practices, (iii) make some form of financial contribution to realize the change, and (iv) that farmers value conservation as a priority goal. Proposed conservation packages were presented to the selected representatives from each of the three villages, and FGDs were used to assess their perception and threshold of risks they are willing to take to adopt the recommended packages. In line with literature on risk management, five common sources of risks in farming including risks associated with production, marketing, financing, human, and institutional were considered to analyze their perceptions (Kahan 2008).

\section{Results and discussion}

Each FGD yielded valuable information on current practices, as well as reasons behind their choices, and presented a good forum to discuss proposed conservation measures.

The question on WTF was the most contentious. However, participants were not convinced on the idea of changing their cropping practices and foregoing current benefits. We linked valuation of ecosystem services to the agricultural risk management literature to unpack some of the drivers that influenced farmers' choices in using scarce irrigation water and their WTF current benefits in lieu of conserving ecosystem services.

We found that water, both in terms of quantity and quality, is a limiting factor in agricultural production in the study area. The Likert scale analysis indicated that water scarcity and quality is a serious concern for farmers in Star Ikan, while water quality holds more weight for farmers in Bugun. In Karchick, which lies at the tail end of the canal, water quality and quantity received from the canal was considered a moderate problem as they mostly rely on groundwater to meet their water demand. On average, $50 \%$ of the respondents from all the three villages considered flood irrigation as a moderate problem for agriculture, while $35 \%$ considered it to be a serious problem, and $15 \%$ considered it a very serious problem. This study thus considered water availability and management as an important factor in farmers' risk management strategies.

Our overall argument hinged upon the notion that in areas such as the study region where alternative sources of employment and income are limited, farmers generally tend to be risk averse and hence opt for certain lower pay-off options in the present than greater but risky future returns. This is in line with the literature on agricultural risk management, which asserts that subsistence farmers' decisions in the face of risk are often based

Table 3 Scenarios proposed by the models for water conservation

\begin{tabular}{|c|c|c|c|c|c|c|c|c|c|}
\hline \multirow[b]{2}{*}{ Method } & \multicolumn{3}{|c|}{ Scenario A } & \multicolumn{3}{|c|}{ Scenario B } & \multicolumn{3}{|c|}{ Scenario C } \\
\hline & $\begin{array}{l}\text { Planned } \\
\text { budget } \\
(\%)\end{array}$ & $\begin{array}{l}\text { Converted } \\
\text { land, } \\
\text { ('000 ha) }\end{array}$ & $\begin{array}{l}\text { Water } \\
\text { saving } \\
\left(\mathbf{m} / \mathbf{l n} \cdot \mathrm{m}^{3} / \mathrm{y}\right)\end{array}$ & $\begin{array}{l}\text { Planned } \\
\text { budget } \\
(\%)\end{array}$ & $\begin{array}{l}\text { Converted } \\
\text { land, } \\
\text { ('000 ha) }\end{array}$ & $\begin{array}{l}\text { Water } \\
\text { saving } \\
\left(\mathbf{m} / \mathbf{l n} \mathrm{m}^{3} / \mathrm{y}\right)\end{array}$ & $\begin{array}{l}\text { Planned } \\
\text { budget } \\
(\%)\end{array}$ & $\begin{array}{l}\text { Converted } \\
\text { land, } \\
\text { ('000 ha) }\end{array}$ & $\begin{array}{l}\text { Water saving } \\
\left(\mathrm{mln} \cdot \mathrm{m}^{3} / \mathrm{y}\right)\end{array}$ \\
\hline $\begin{array}{l}\text { Drip- } \\
\text { irrigated } \\
\text { cotton }\end{array}$ & $30 \%$ & 10,7 & 51,9 & $20 \%$ & 7,1 & 34,6 & $50 \%$ & 17,9 & 86,6 \\
\hline $\begin{array}{l}\text { Sprinkler } \\
\text { irrigated } \\
\text { alfalfa }\end{array}$ & $20 \%$ & 6,7 & 14,0 & $10 \%$ & 3,3 & 7,0 & $20 \%$ & 6,7 & 14,0 \\
\hline $\begin{array}{l}\text { Drip- } \\
\text { irrigated } \\
\text { orchards }\end{array}$ & $50 \%$ & 20, & 134,0 & $70 \%$ & 28,0 & 187,6 & $30 \%$ & 12,0 & 80,4 \\
\hline Total & $100 \%$ & 37.4 & 199.9 & $100 \%$ & 38.5 & 229.2 & $100 \%$ & 36.5 & 181.0 \\
\hline
\end{tabular}


on careful evaluation of different alternatives with the end goal of ensuring food security and maximizing profits while minimizing risk (Miller et al. 2004; Greiner et al. 2008; Sulewski and Kloczko-Gajewska 2014). This line of argument is also supported by ecosystem literature which recognizes that farmers' risk management behaviors have direct implication on ecological performances and that individuals tend to prefer benefits to be provided sooner than later and to postpone costs to the future as opposed to incurring them in the present (Fisher et al. 2011; Boelee et al. 2013; Mouysset et al. 2013). The study used five areas of risk including production, marketing, finance, human, and institutional, as evaluation criteria to develop better understanding of farmers' current decisions on the management and use of scarce irrigation water in the three villages, and their reluctance to adopt alternatives proposed by the model. Farmers' current risk management strategies are first presented within the context of the five areas of risk, followed by a presentation of anticipated or perceived changes in risk should they opt to adopt recommended packages and its effect on their WTF current benefits.

\section{Risk management under current farming practices}

We applied risk management principles to understand farmers' current use of land and water in relation to common farming practices and the types and extent of risks they take to sustain their livelihoods.

\section{Production risks}

These refer to risks associated with uncertainty in weather, pest, and other biophysical and ecological factors that could result in yield losses (Kahan 2008). Although Karchick, Star Ikan, and Bugun are considered growing villages, off-farm income generating opportunities are quite limited and agriculture remains the main source of livelihood. Production risks thus bear great weight in farmers' decision making. A closer look at farmers' agricultural practices, primarily crop choices and irrigation methods in the three villages, indicated that farmers grow three to five main types of crops that are carefully selected to (i) generate a certain minimum yield under existing biophysical conditions including water scarcity, land size and quality, (ii) generate a certain minimum family income, (iii) minimize dependence on local market for own consumption, and (iv) meet household food needs.

Cotton is grown as a cash crop in all three villages, although the actual amount grown varies depending on land size, access to water, and marketing opportunities. Cotton is harvested once a year and offers farmers some level of income security. Wheat (soft) is also harvested once a year and is grown in Karchick and Staryi Ikan villages to meet household demand for animal feed and flour used in bread making-a main staple in rural Kazakhstan. In addition, wheat is considered an essential crop because flour is one of the most expensive commodities in both local markets.

The other common crop grown in the three villages is alfalfa. In Karchick and Star Ikan, alfalfa is grown to meet basic feed requirement of their livestock and a small portion of it is sold in the local market. Alfalfa is often harvested three to four times a year depending on water availability and hence offers farmers year-round security to feed their livestock and whenever possible generate some income. In Bugun, where water is readily available, alfalfa is grown as the main cash crop to meet the growing demand in Shymkent-one of the most densely populated cities in Kazakhstan, and is also as an ideal crop that can grow under saline conditions. Most farmers grow alfalfa based on contractual agreements with suppliers in the city, though a small percentage of the produce is also kept as feed for own livestock. By diversifying their crops that have different water requirements and harvesting periods, farmers in all three villages meet different household needs and minimize production risks associated especially with those that have higher water demand.

\section{Market risks}

While changes in market prices are outside the control of any individual farmer, market trends which signify demand patterns and shifts in costs and revenues of production highly influence farmers' production decisions. Volatile input and output market prices thus present serious risks to farmers (Kahan 2008). In the case of the villages under consideration, results of the study clearly indicated a direct relationship between crop choices and marketing opportunities. For instance, farmers in Karchick and Star Ikan dedicate a relatively smaller amount of their land to alfalfa which commands low demand and hence price in the local or nearby markets, but opt instead to grow cotton which can fetch a good price and is expected to do so if current upward trend in the international market continues. Similarly, in Bugun, farmers' decision to increase their production of alfalfa as a cash crop as opposed to cotton is influenced by the demand in Shymkent. The choice to grow grain in Karchich and Star Ikan is also influenced by market prices which make purchasing flour for home consumption an expensive alternative, hence prompting farmers to grow their own grain to ensure household food security. Thus, by diversifying their crop choices, farmers minimize market risks in one or more crops.

\section{Institutional risks}

These refer to potential threats from unexpected changes in policy and/or changes in the provision of agriculture-related 
services from formal or informal institutions (Kahan 2008). Subsidies are common strategies used to influence agricultural practices in Kazakhstan. For instance, governments encourage or discourage the production of certain crops and agricultural technologies in selected parts of a country by providing incentives in the form of cheaper agricultural inputs, financial, and advisory services in support of recommended alternatives and facilitating market outlets. For instance, personal communication with Mr. Karl Anselm revealed that the production of irrigated wheat is generally discouraged in South Turkestan as higher yields and better quality wheat can be produced in other rainfed parts of the country. Hence, the government offers substantial subsidies to wheat growers in rainfed agroecosystems making wheat growers in the Turkestan region less competitive.

Provisioning and pricing of public goods also influences farmers' decisions in the use and management of natural resources including the use of irrigation water. In this case, the lack of clear guidelines for sharing the canal water poses substantial risk for downstream users whose access to water depends on the management and level and pattern of utilization of water by upstream users. Farmers in Karchik, and to a certain extent Staryi Ikan, thus cannot grow crops with high crop water requirement as they do not have legal assurance that their water supply will not change. Crop choices are thus made with such risks in mind.

\section{Financial risks}

These risks are associated with unpredictable changes in interest rates and terms of borrowing. As formal and non-formal agricultural credit services are uncommon in all three villages, risks associated with repayments and interest rates play minimal role in farmers' decision making processes. However, another key component in risk management is keeping the cost of production as low as possible. Such practices provide one option for farmers to ease their liquidity constraints, maximize profit from their production, and serve as a cushion in times of production loss. Famers in the three villages use flood irrigation to water their crops and use manual labor to harvest their crops, with the exception of alfalfa which is harvested using combiners. Adoption of new and improved irrigation practices will therefore mean increased cost of production, higher need for financial capital, and higher financial risk under bad weather conditions.

\section{Human risks}

Refer to unexpected illnesses and or death which could influence farming decisions. While both types of risks are indeed part of any farming decision processes, we did not find any evidence that links these risks to farmers' crop or irrigation choices in the three villages.
Therefore, as described above, production, marketing, and institutional risks shape farmers' decision in crop choices, land use, and irrigation water schedules and methods.

\section{Anticipated changes in risk}

Discussions on adoption of proposed conservation measures provided interesting insight into farmers' perception of risks associated with the various recommendations for change. Information collected from each village was analyzed in terms of potential changes in risk in relation to production, marketing, financial, and institutional risks.

\section{Production risk}

Assuming that all other things will remain the same, the model recommends for farmers in Bugun to produce more of drip-irrigated cotton and orchards, which will only be possible at the cost of reduced production in alfalfa, the main cash crop for the area, and/or other crops commonly grown in the area including corn, sunflower, and wheat. While farmers are familiar with growing cotton as a cash crop and hence have a good expectation of yield, growing cotton under drip irrigation is a new concept. This was clearly expressed during the FGDs where farmers voiced their concern in growing cotton with drip irrigation under saline conditions-a major challenge for the agricultural sector in the area.

Orchards are also grown in the area though at a very small scale-mainly for home consumption or for sale in local markets. Increasing its production through drip irrigation thus presented a different challenge. Among the concerns raised are their ability to grow under saline conditions (especially under drip irrigation), susceptibility to pest and diseases, vulnerability to weather changes, and need for greater investment in upkeep, harvesting, preserving, and packaging. Lack of information on potential market outlets and profitability of the various fruits from the orchards was also a source of apprehension among the farmers in Bugun.

Similarly, recommendations to grow more of drip-irrigated cotton and sprinkler-irrigated alfalfa in the Star Ikan village posed a serious challenge for the farmers who will have to make a corresponding reduction in land and water allocated for the production of wheat, which is an essential crop to ensure household food security. The lack of information on expected yield from drip-irrigated alfalfa also added to farmers' concern of increased risk with the change. The viability of growing alfalfa (a crop that is commonly known to require more water than cotton and wheat) under relatively severe water shortages, and in the absence of a governing body or law that could guarantee water allocation from the canal, was also questioned by farmers in Star Ikan, but more so in Karchik. 


\section{Marketing risk}

Under Scenario B, farmers in Bugun, Star Ikan, and Karchik were encouraged to increase their production of one or more crops at the expense of other crops. For instance, farmers in Bugun were asked to grow more cotton and orchards under drip irrigation and those in Star Ikan were encouraged to grow more drip-irrigated cotton and sprinkler-irrigated alfalfa, while farmers in Karchik were requested to increase their production of alfalfa through sprinkler irrigation.

Farmers in Bugun and Star Ikan already grow cotton as a cash crop and are thus quite familiar with its marketing potential. Nonetheless, they were concerned with increasing their production of cotton as prices are closely linked with the international market and hence quite volatile. They also questioned their ability to generate profit with the anticipated increase in the cost of production, and in competition with other farmers in other parts of the region who continue to use flood irrigation. Their concerns are in line with the arguments for equitable distribution of benefits and costs where they questioned the rationale behind the proposed conservation efforts while others elsewhere could be overexploiting the resource.

The opportunity cost of increasing production of cotton and orchards in Bugun was discussed in light of potential decreases in the production of alfalfa-a dominant cash crop catering to a guaranteed market and hence income for the household. Similar discussions were also held in Karchik where farmers expressed their concerns in foregone opportunities to grow cotton which serves as the main source of income for the household.

The ability of local markets to absorb increased production of alfalfa at an increased cost of production associated with installing and managing sprinkler irrigation systems was also questioned by farmers in Star Ikan and Karchik. Livestock contributes only less than 15\% to household income and hence the demand for alfalfa at the household level is also too low to make use of possible unsold surplus from the proposed increase.

\section{Financial risk}

Adoption of new technologies often comes with associated financial cost and the proposed changes under scenario B are no different. The model projects that without subsidies, farmers could incur between USD 336 and 2798 , to convert their respective fields and comply with the recommendations of the model. The corresponding figures under government subsidy scenario are between USD 336 and 2596 (Table 3). The subsidies offered certainly reduce the cost of adoption but unfortunately the cost is still substantially higher than what the farmers can afford without taking either formal or informal loan which would add to their level of risk. For farmers in Bugun, in addition to costs associated with the installation and upkeep of drip irrigation, farmers will also need to invest in alternative salinity management interventions in lieu of flood irrigation which was partly justified on grounds of flashing out the salt. This is especially true in the case of shifting to drip-irrigated orchards which is not covered under current government subsidies for the area (Table 4). For farmers in Karchik and Star Ikan, the change could also result in reduced production of wheat which would in turn translate into increased financial burden to purchase wheat flour to meet household needs.

\section{Institutional risk}

Current subsidy provisions offer some, but not sufficient, incentive for adopting recommended packages. However, potential shifts in such policies as well as regulatory frameworks for managing the disbursement and use of canal water still pose some level of risk.

\section{Farmers WTF current benefits}

As detailed in the section above, adoption of interventions recommended by the models does raise the risk bar for farmers across the production, marketing, financial, and institutional contexts. The analysis is summarized below as Table 5. Farmers in the study region weigh all their options and choose the alternatives that present relatively higher payoffs and lower risks. The level of knowledge and perception hence play a major role in influencing farmers' assessment of risk. Small-scale farmers are even more risk-averse as compared to large-scale commercial farmers because even the slightest shock could result in major shifts in the delicate balance maintained and result in big consequences (Kahan 2008).

Based on the above argument, farmers in Karchick and Star Ikan who own relatively smaller lands as compared to those in Bugun will be more affected. Farmers' resistance to adopt the recommendations made by the model can thus partly be explained by the level of risk

Table 4 Cost of conversion

\begin{tabular}{lll}
\hline & \multicolumn{2}{l}{$\begin{array}{l}\text { Net cost (cost - income gained): } \\
\text { USD per hectare }\end{array}$} \\
\cline { 2 - 3 } $\begin{array}{l}\text { Recommended } \\
\text { conversions }\end{array}$ & Without subsidies & With subsidies \\
\hline $\begin{array}{l}\text { From flood-irrigated } \\
\text { cotton to drip-irrigated } \\
\text { cotton }\end{array}$ & 2475.2 & 2293 \\
$\begin{array}{l}\text { From flood-irrigated } \\
\text { alfalfa to sprinkler- } \\
\text { irrigated alfalfa }\end{array}$ & 2798.4 & \\
$\begin{array}{l}\text { From flood-irrigated } \\
\text { orchards to drip- } \\
\text { irrigated orchards }\end{array}$ & 336 & 2596.4 \\
\hline
\end{tabular}

Source: ICARDA 2015 
Table 5 Risk analysis—summary

\begin{tabular}{lll}
\hline Village & Current practice & Proposed change \\
\hline Karchick & $\begin{array}{l}\text { Crop choice in order of land } \\
\text { allocation }\end{array}$ & Sprinkle-irrigated alfalf \\
& $\begin{array}{l}\text { 1. Cotton (main cash crop) } \\
\text { 2. Wheat (for subsistence) }\end{array}$ \\
& $\begin{array}{l}\text { 3. Alfalfa (mainly for livestock } \\
\text { upkeep) }\end{array}$ \\
& Irrigation method: flood irrigation
\end{tabular}

Star Ikan

Crop choice in order of land
allocation
1. Cotton (main cash crop)
2. Wheat (for subsistence)
3. Alfalfa (for livestock upkeep)
Irrigation method: flood irrigation

Bugun

Crop choice in order of land
allocation
1. Alfalfa (main cash crop)
2. Cotton
3. Corn
Irrigation method: flood irrigation

Sprinkle-irrigated alfalfa and drip-irrigated cotton

Drip-irrigated cotton and orchards

\begin{abstract}
Anticipated risk associated with proposed change
Production-Alfalfa requires more water, there is uncertainty on water availability and reduction/no production of wheat and cotton which are essential to support household flour demand and generate income respectively

Marketing - Livestock only contributes to about $15 \%$ of household income in the area so alfalfa has very low demand in local markets fetching low price, and wheat and flour are very expensive to buy; therefore, without own production, households' food security will be jeopardized Finance-The cost of production will be higher with introduction of new irrigation systems potentially reducing their profit margin, with risks associated with their ability to afford the initial investment cost of sprinkle irrigation as well as upkeep

Institutional-There is uncertainty on future regulations on water sharing along the canal and the availability of subsidies or credit to enable adoption
\end{abstract}

Production-Alfalfa requires more water, there is uncertainty on water availability and reduction/no production of wheat which is essential to support household flour demand Marketing - Alfalfa has very low demand in local markets fetching low price; wheat and flour are very expensive to buy and will increase households financial burden

Finance-The cost of production will be higher with the introduction of two new irrigation systems potentially reducing their profit margin, with risks associated with their ability to afford the initial costs of investment and upkeep of both sprinkle and drip irrigation systems

Institutional-There is uncertainty on future regulations on water sharing along the canal and the availability of subsidies or credit to facilitate adoption

Production-Alfalfa is the main cash crop produced under contractual farming; the production cost of orchards including harvesting, processing, preserving, and packaging is considered cumbersome; and drip irrigation will enhance their current challenge of farming with saline water

Marketing - The price of cotton is linked with the international market and highly volatile and hence not worth the risk to forego a secured market in alfalfa; and marketing of fruits is not well known

Finance-The cost of production and maintenance of orchards is considered expensive

Institution—Orchards are not included in government subsidy associated with the transition. Decisions to move from their relative "comfort zone" or familiar risks with known probability of occurrence to uncertainty, i.e., a realm of unknown probability, are not easy to make (Fig. 2). A closer look at potential risks associated with proposed changes is analyzed and presented in the section below.

In this particular case, the SWAT and RIOS models make their simulations assuming the total land holding and amount of irrigation water available to each household to remain constant. The models recommended that farmers should not only change their land and water allocation to grow more of one or two crops, but also change their irrigation methods. Therefore, the recommended changes are in essence requests for shifts in allocation of resources in favor of one or more crops to conserve water at the basin level but at the expense of one or more other crops. Consequently, the lack of information on potential effects on yield, markets and hence farm profits, and availability of other alternatives to ensure household food and income security pushes farmers into the realm of uncertainty.

What is quite interesting is that, while farmers respond negatively to WTF current crop allocations, their response to adoption of improved irrigation methods was quite different. When asked if they were willing to pay for the installation of the proposed irrigation methods, farmers in both Karchick and Staryi Ikan responded positively, though under the condition that the government covers part of the cost. Such stated preferences demonstrate that farmers do value and desire to conserve irrigation water for future use but strategies for conservation should maintain or at best minimize farmers' food security risks through some level of assurance of yield and income. In Bugun, where salinity and not water scarcity poses the greatest challenge 


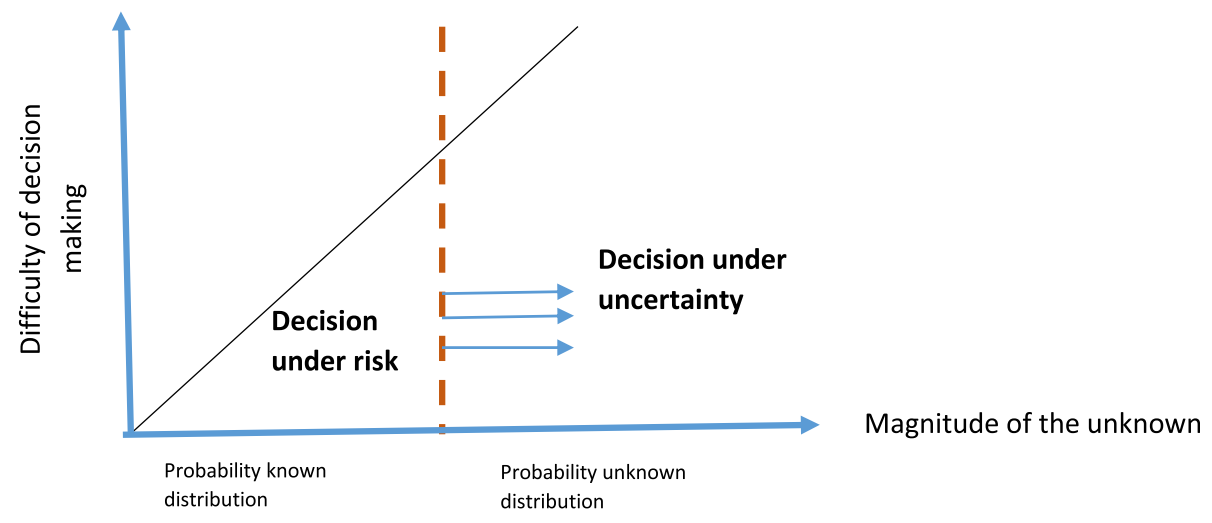

Fig. 2 Decision making under varying levels of information

to agricultural production, farmers were not willing to invest in drip irrigation. This is a signal for the need to explore varying approaches and incentive systems tailored to fit different social, economic, and biophysical conditions.

\section{Conclusions}

Valuation of ecosystem services is important to provide evidence for decision makers to invest in sustainable management of natural resources. $\mathrm{CV}$ is the dominant approach used to assign monetary value to ecosystem services on the basis of stated preferences established under simulated markets and expressed in the form of either WTP for services or WTA compensation for them. In this paper, we have argued for WTF as a complementary qualitative approach to assess stakeholders' valuation of ecosystem benefits by focusing on the trade-offs they are willing to make to improve water and land management and use. In so doing, the approach avoids the eminent bias associated with the other approaches that focus on financial transactions-be it anticipated income (WTA) or payments (WTP). The approach was applied as a case study to assess stakeholders' valuation of ecosystem services in three villages located at the beginning, middle, and tail end of the Turkestan canal in South Kazakhstan. Farmers' responses were analyzed through the lens of agricultural risk management to demonstrate the added benefits of using WTF, to unpack the various complexities associated with stakeholders' decisions on the management and use of natural resources. In so doing, the study highlighted some of the limitations of decision support tools and other valuation approaches in capturing the delicate trade-offs that influence the valuation and management of ecosystem services and provided possible explanations for the convergence and/or divergence between farmer responses and model recommendations.

One of the major findings of this paper is that despite their stated preference to conserve and adopt a more sustainable management and use of ecosystem services, like any other risk-averse agent, farmers opt for options that offer the maximum current benefit and the lowest production, marketing, financial, and institutional risks. Lack of information on potential effects of proposed conservation measures on yield, marketability and hence farm profits, and availability of other alternatives to ensure household food and income security is a critical factor influencing farmers' responses pushing them from a scenario of risk management into the realm of decision under uncertainty. The optimal recommendations from two watershed models (SWAT and RIOS) remain predominantly divergent from farmers' preferences as the drivers that inform society's value for the services go beyond the environmental and biophysical to include the social, economic, and cultural dimensions-most of which are not fully and explicitly captured by the models. It is thus important for researchers to consider the compatibility and implications of proposed biophysical interventions with socio-economic conditions on the ground. The findings of the study also highlight a role for extension agents to raise awareness on the expected benefits of adopting new technologies to reduce perceived risk and build confidence through evidence based knowledge. Based on the study, we also recommend that policy makers promote appropriate incentives to encourage technology adoption and income diversification to reduce reliance on natural resources, make adoption affordable through credit, and enhance market outlet strategic crops.

While the results remain specific to the case under consideration, they are consistent with literature that assert that farmers' behaviors have direct implication on ecological performances and that individuals tend to prefer benefits to be provided sooner than later and tend to postpone costs to the future as opposed to incurring them in the present. The findings also present important basis for expanding the discussion on ecosystem valuation methods, offer an insight to decision makers to identify appropriate measures that can influence 
stakeholders' perceptions of risk, and encourage sustainable management and use of ecosystem services.

The findings of this study will be useful for researchers seeking novel ways to assess stakeholder valuation of ecosystem services and offering extension agents and decision makers opportunities to devise natural resource management strategies that are cognizant of the need to maintain the delicate balance between ensuring human well-being and sustainable management and use of ecosystem services.

It is important to note that, while the WTF approach has been found effective in analyzing this particular study, it needs to be tested in other cases and with larger number of FGDs. Linking this approach with household level quantitative data for more in-depth analysis will be a subject for future research.

\section{Abbreviations}

CAREC: Regional Environmental Center for Central Asia; CV: Contingent valuation; FGDs: Focus group discussions; ICARDA: International Center for Agricultural Research in Dry Areas; MCM: Million cubic meters; RIOS: Resource Investment Optimization System; SWAT: Soil and Water Assessment Tool; WTA: Willingness to accept (payment); WTF: Willingness to forego; WTP: Willingness to pay

\section{Acknowledgements}

We thank the farmers who have willingly and unreservedly shared their thoughts with us through active and candid discussions. We also acknowledge the support and contributions of all the staff from CAREC who organized the filed visits and the translators who made it possible for non-Kazak speakers to actively engage in the discussions.

\section{Funding}

This study was funded by the CGIAR Research Program on Water, Land and Ecosystems (WLE) and is a result of a collaborative research by the International Center for Agricultural Research in the Dry Areas (ICARDA) and the Regional Environmental Center for Central Asia (CAREC)

\section{Availability of data and materials}

Qualitative data for the paper was collected through FGDs held with members of the community.

\section{Authors' contributions}

$\mathrm{BD}$ served as the research team leader responsible for designing the lead questions for the FGDs, conducting the FGDs, analyzing the data collected, and preparing the preliminary manuscript. LK, BZ, and SZ assisted in conducting the FGDs and helped in contextualizing the questions and results of the analysis to local conditions. VN led the research on valuation of ecosystem services in the study area using Soil and Water Assessment Tool (SWAT) and Resource Investment Optimization System (RIOS) models. All authors read and approved the final manuscript.

\section{Authors' information}

Bezaiet Dessalegn is a social scientist at the International Center for Agricultural Research in the Dry Areas (ICARDA). Her research interests include linking research to development, gender, and sustainable management of natural resources. P.O. Box 950764 Amman, Jordan. + 962-7954-9673 B.Dessalegn@cgiar.org Ludmilla Kiktenko is a resource mobilization coordinator at the Regional Environmental Centre for Central Asia (CAREC). Her research interests include environmental impact assessment, climate change and water resources management.

Balzhan Zhumagazina is a project assistant at the Regional Environmental Centre for Central Asia (CAREC). Her research interests include sustainable development and water management.

Saltanat Zhakenova is a program manager at the Regional Environmental Centre for Central Asia (CAREC). Her research interests include environmental indicators, shared environmental information systems, and sustainable development.

Vinay Nangia is a senior scientist at the International Center for Agricultural Research in the Dry Areas (ICARDA). His research interests include hydrological modeling, agricultural water management, and environmental impact assessment.

Ethics approval and consent to participate

Not applicable.

\section{Competing interests}

The authors declare that they have no competing interests.

\section{Publisher's Note}

Springer Nature remains neutral with regard to jurisdictional claims in published maps and institutional affiliations.

\section{Author details}

${ }^{1}$ International Center for Agricultural Research in the Dry Areas (ICARDA), P.O. Box 950764, Amman, Jordan. ${ }^{2}$ Regional Environmental Centre for Central Asia (CAREC), 40 Orbita-1, 050043 Almaty, Republic of Kazakhstan. ${ }^{3}$ International Center for Agricultural Research in the Dry Areas (ICARDA), P.O. Box 6299, Rabat Instituts, Rue Hafiane Cherkaoui, Rabat, Morocco.

Received: 3 January 2018 Accepted: 17 May 2018

Published online: 11 June 2018

\section{References}

Asamoah G, Wiafe ED (2016) Valuation of provisioning ecosystem services and utilization in three rural communities of Ghana. International Journal of Natural Resource Ecology and Management 1:79-87

Bagstad K, Semmens DJ, Waage S, Winthrop R (2013) A comparative assessment of decision-support tools for ecosystem services quantification and valuation. Ecosystem Services 5:27-39

Barbier E, Czajkowski M, Hanley N (2016) Is the income elasticity of the willingness to pay for pollution control constant? Environmental and Resource Economics. 68:663-682

Bateman I, Munro A, Rhodes B, Starmer C, Sugden R (1997) A test of the theory of reference dependent Preferences. Quarterly Journal of Economics 112(2): 479-505.

Bateman IJ, Mace GM, Fezzi C, Atkinson G, Turner RK (2011) Economic analysis for ecosystem service assessments. Environmental and Resource Economics 48:177-218

Baumgartner S, Drupp MA, Munz JM, Meya JN, Quaas MF (2017) Income inequality and willingness to pay for environmental public goods. Journal of Environmental Economics and Management 85:35-61.

Boelee E, Scherr S, Pert E, Barron J, Finlayson M, Descheemaeker K, Milder J, Fleiner R, Nguyen-Khoa S et al (2013) Management of water and agroecosystems in landscape for sustainable food security. In: Boelee $E$ (ed) Comprehensive assessment of water management in agriculture series, 10th edn. Oxfordshire, United Kingdom, pp 171-185

Braun V, Clarke V (2006) Using thematic analysis in psychology. Qualitative Research in Psychology 3:77-101

Chee YE (2004) An ecological perspective on the valuation of ecosystem services. Biological Conservation 120:59-565

Ciriacy-Wantrup SV (1947) Capital returns from soil conservation practices. American Journal of Agricultural Economics 29:1181-1196

Cowling RM, Egoh B, Knight AT, O'Farrell PJ, Reyers B, Rouget M, Roux D, Welz A, Wilhelm-Rechman A (2008) An operational model for mainstreaming ecosystem services for implementation. Proceedings of the National Academy of Sciences of the United States of America (PNAS) 105:9483-9488

Daily GC (ed) (1997) Nature's services: societal dependence on natural ecosystems. Island Press, Washington, DC

Dasgupta P, Levin S, Lubchenco J (2000) Economic pathways to ecological sustainability. BioScience 50:339-345

De Groot RS, Wilson MA, Boumans RMJ (2002) A typology for the classification, description, and valuation of ecosystem functions, goods, and services. Ecological Economics 41:393-408

Diamond P (1996) Testing the internal consistency of contingent valuation surveys. Journal of Environmental Economics and Management 30:265-281 
Drupp MA, Meya JN, Stefan B, Quaas MF (2017) CAU - Christian-AlbrechtsUniversitati zu Kiel, Department of Economics, Economics Working Paper No 2017-08. Economic Inequality and the Value of Nature -. Issn 2193-2476 (Version 16.11.2017)

Farber SC, Costanza R, Wilson MA (2002) Economic and ecological concepts for valuing ecosystem services. Ecological Economics 41:375-392

Felipe-Lucia MR, Comín FA, Escalera-Reyes J (2014) A framework for the social valuation of ecosystem services. AMBIO A Journal of the Human Environment 44:308-318

Fisher, B., I. Bateman, and R.K. Turner. 2011. Valuing ecosystem services: benefits, values, space and time. Environment for development. The United Nations Environment Programme. Ecosystem Services Economics (ESE) Working Paper Series - Paper No. 3

Garrod G, Willis K (1999) Economic valuation of the environment. Edward Elgar Publishing Ltd., Cheltenham

Greiner R, Patterson L, Miller O (2008) Motivation, risk perceptions and adoption of conservation practices by farmers. Agricultural Systems 99:86-104

Hanneman M (1991) Willingness to pay and willingness to accept: how much can they differ. American Economic Review 81(3):635-647

Hein L, Koppen KV, de Groot RS, van lerland EC (2006) Spatial scales, stakeholders and the valuation of ecosystem services. Ecological Economics 57(2):209-228

Horowitz JK, McConnell KE (2002) A review of WTA/WTP studies. Journal of Environmental Economics and Management 44:426-447

International Center for Agricultural Research in the Dry Areas (ICARDA) and Regional Environmental Center for Central Asia (CAREC). 2015. Final project report: valuation of ecosystem services for improving agricultural water management in Kazakhstan. Amman, Jordan

Kahan D (2008) Managing risk in farming. Food and Agriculture Organization (FAO) Farm Management Extension Guide. Rome. Retrieved 18 Dec 2016, from http://www.fao.org/uploads/media/3-ManagingRisklnternLores.pdf

Kahneman D, Knetsch JL, Thaler RH (1990) Experimental tests of the endowment effect and the Coase theorem. Journal of Political Economy. 98:1325-1348

Kiktenko L, Dessalegn B, Charre S, and Nangia V (2015) Markets offer women opportunities to capitalize on ecosystem services. [Blog post]. Retrieved 12 Nov 2016, from https://wle.cgiar.org/markets-offer-women-opportunitiescapitalize-ecosystem-services

Knetsch JL (1990) Environmental policy implications of disparities between willingness to pay and compensation demanded measures of values. Journal of Environmental Economics and Management 18:227-237

Knetsch JL, Sinden JA (1984) Willingness to pay and compensation demanded: experimental evidence of an unexpected disparity in measures of value. The Quarterly Journal of Economics 99:507-521

Liu S, Costanza R, Farber S, Troy A (2010) Valuing ecosystem services: theory, practice, and the need for transdisciplinary synthesis. Annals of the New York Academy of Sciences 1185:54-78

Luyet V, Schlaepfer R, Parlange MB, Buttler A (2012) A framework to implement stakeholder participation in environmental projects. Journal of Environmental Management 111:213-219

Mansfield C (1999) Despairing over Disparities: Explaining the difference between willingness to pay and willingness to accept. Environmental and Resource Economics 13(2):219-234

MEA- Millennium Ecosystem Assessment (2005) Ecosystems and human wellbeing: synthesis. Island, Washington, D.C.

Miller A, Dobbins C, Pritchett J, Boehlje M, Ehmke C (2004) Risk Management for Farmers. Department of Agricultural Economics, Purdue University, Staff Paper 04-11. West Lafayette.

Mouysset L, Doyen L, Jiguet F (2013) How does economic risk aversion affect biodiversity? Ecological Applications 23:96-109

Nangia V, Charre S, Inozemtseva A, Raghavan S, Mulla D (2015) Agricultural wate management and ecosystem services in the Aral-Syrdarya watershed, Kazakhstan-Searching for novel ways to share water and improve ecosystem services in Kazakhstan. 8th Ecosystem Services Partnership (ESP) Conference. 9-13 November 2015. Stellenbosch, South Africa.

Nunes PALD, van den Bergh JCJM (2001) Economic valuation of biodiversity: sense or nonsense? Ecological Economics 39:203-222

Randall A (1987) Resource Economics. Wiley, NY

Reed MS (2008) Stakeholder participation for environmental management: a literature review. Biological Conservation 141:2417-2431
Shapansky B, Adamowicz W, Boxall P (2002) Measuring forest resource values: an assessment of choice experiments and preference construction methods as public involvement tools. Department of Rural Economy, Project Report 0203, University of Alberta Edmonton, Canada. Retrieved 12 Dec 2016, from http://ageconsearch.umn.edu/bitstream/24036/1/pr020003.pdf

Singh R, Turner N, Pandey C (2011) Tinni rice (Oryza rufipogon Griff.) production: an integrated sociocultural agroecosystem in eastern Uttar Pradesh of India. Environmental Management 49:26-43

Sulewski P, Kloczko-Gajewska A (2014) Farmers' risk perception, risk aversion and strategies to cope with production risk: an empirical study from Poland. Studies in Agricultural Economics 116:140-147

TEEB - The Economics of Ecosystems and Biodiversity (2012) The economics of ecosystems and biodiversity. In: Kumar P (ed) Ecological and economic foundations. Routledge, New York

Willing R (1976) Consumer's surplus without apology. The American Economic Review 66 (4): 589-597.

\section{Submit your manuscript to a SpringerOpen ${ }^{\circ}$ journal and benefit from:}

- Convenient online submission

- Rigorous peer review

- Open access: articles freely available online

- High visibility within the field

- Retaining the copyright to your article

Submit your next manuscript at $>$ springeropen.com 